\title{
PENGETAHUAN BERHUBUNGAN DENGAN STIGMA PADA ORANG TERKONFIRMASI POSITIP CORONA VIRUS DISEASE -19
}

\author{
Ni Kadek Muliawati ${ }^{1}$, Ni Luh Putu Dewi Puspawati ${ }^{2}$, Ni Kadek Kembar Dani \\ Sintaningsih ${ }^{3}$ \\ 1,2,3 STIKes Wira Medika Bali \\ Email: muliawati.wika@gmail.com
}

\begin{abstract}
ABSTRAK
Orang yang terkonfirmasi Corona Virus Desease 19 (covid 19) di masyarakat menyebabkan munculnya stigma yang dapat menyebabkan terjadinya diskriminasi. Penelitian ini dilakukan untuk mengetahui hubungan pengetahuan dengan stigma pada orang terkonfirmasi positip corona virus disease -19 di Banjar Tegal, Desa Bebalang Bangli Propinsi Bali. Deskriptif korelasi merupakan jenis penelitian yang digunakan dengan desain penelitian kuantitatif. Sampel sebanyak 89 orang dengan teknik simple random sampling. Intrumen menggunakan kuesioner yang disebarkan secara online melalui google form. Pengambilan data menggunakan google form dengan 10 pertanyaan terkait pengetahuan dan 30 pertanyaan terkait stigma. Analisis data menggunakan spearman rank dengan hasil mayoritas pengetahuan kategori cukup yaitu 65 orang $(73,0 \%)$, sebagian besar stigma kategori sedang yaitu 54 orang $(60,7 \%)$. Analisis bivariat didapatkan nilai $\mathrm{p}$ value sebesar 0,000 dan nilai $\mathrm{r}$ sebesar 0,548 . Ada hubungan pengetahuan dengan stigma pada orang terkonfirmasi positip corona virus disease -19 di Banjar Tegal, Desa Bebalang Bangli Provinsi Bali. Semakin baik tingkat pengetahuan semakin rendah stigma terhadap orang terkonfirmasi positif covid-19. Hasil penelitian dapat digunakan sebagai acuan pelaksanaan program promosi kesehatan untuk mengurangi stigma pada orang terkonfirmasi positip corona virus disease -19 .
\end{abstract}

Kata kunci : Pengetahuan, stigma, covid -19 


\title{
KNOWLEDGE RELATED TO STIGMA IN CORONAVIRUS DISEASE -19 CONFIRMED PEOPLE
}

\begin{abstract}
People who are confirmed to have Corona Virus Disease 19 (covid 19) in the community cause a stigma that can lead to discrimination. This study was conducted to determine the relationship between knowledge and stigma in people who were confirmed to be positive for corona virus disease -19 in Banjar Tegal, Bebalang Village, Bangli, Bali Province. Descriptive correlation is a type of research used with a quantitative research design. The sample is 89 people with simple random sampling technique. The instrument uses a questionnaire which is distributed online via google form. Data collection using google form with 10 questions related to knowledge and 30 questions related to stigma. Data analysis using Spearman rank with the result that the majority of knowledge in the sufficient category is 65 people (73.0\%), most of the stigma is in the moderate category, namely 54 people (60.7\%). Bivariate analysis obtained $p$ value of 0.000 and $r$ value of -0.548 . There is a relationship between knowledge and stigma in people who are confirmed to be positive for corona virus disease -19 in Banjar Tegal, Bebalang Village, Bangli, Bali Province. The better the level of knowledge, the lower the stigma against people who are confirmed positive for COVID-19. The results of the study can be used as a reference for implementing health promotion programs to reduce stigma in people who are confirmed positive for the corona virus disease -19 .
\end{abstract}

Keywords: Knowledge, stigma, covid- 19

\section{PENDAHULUAN}

Corona virus desiase 19 (covid 19) adalah penyakit pada saluran pernapasan disertai dengan pneumonia atau radang paru-paru yang disebabkan oleh virus corona. Kasus ini pertama kali terdeteksi pada Desember 2019 di Kota Wuhan Provinsi Hubei, Tiongkok berkaitan dengan mengkonsumsi makanan yang tidak biasa, salah satunya tikus, kelelawar dan makanan laut lainnya (Susilo, 2020). Pada awalnya corona virus merupakan virus yang menginfeksi hewan, namun beberapa dari jenis virus tersebut mampu menginfeksi manusia. Gejala yang timbul dari infeksi virus corona ini adalah mirip gejala flu kemudian berkembang menjadi penyakit yang menginfeksi paru dan berlanjut sampai 
terjadi kegagalan organ lain (Susilo, 2020).

Dari Kota Wuhan virus corona ini menyebar ke seluruh penjuru China, kemudian ke berbagai wilayah di Eropa, ke Amerika, Wilayah Asia dan termasuk Indonesia (Ai et al., 2020). Menurut data World Health Organization terdapat 194.080.019 orang terkonfirmasi positip dan sebanyak 4.162.304 meninggal dunia (WHO, 2021). Di Indonesia terdata 3,19 juta jiwa terkonfirmasi positip, sebanyak 84,766 jiwa meninggal dunia dan sebanyak 2,55 jiwa sembuh (Kasus Covid Indonesia, 2021). Di Provinsi Bali terdata 21.030 jiwa terkonfirmasi dan sebanyak 586 jiwa meninggal dunia, sedangkan kasus covid -19 di Kabupaten Bangli Propinsi Bali sebanyak 3158 jiwa terkonfirmasi, sebanyak 2688 jiwa sembuh dan sebanyak 134 jiwa meninggal dunia (Info Corona Pemerintah Provinsi Bali, 2021).

Pandemi covid -19 memengaruhi segala aspek kehidupan, baik dibidang kesehatan, ekonomi maupun social budaya. Beberapa dampak yang ditimbulkan diantaranya perilaku baru menjaga kebersihan dan rajin cuci tangan, menghindari transportasi umum, PHK dan bekerja sementara di rumah, penurunan pendapatan pada sektor tertentu, peningkatan pengeluaran, kebiasaan berbelanja online dan penggunaan uang elektronik (BPS, 2020). Dampak lain yang juga ditimbulkan adalah stigma sosial, dimana pandemi covid-19 dapat menimbulkan kebingungan, kecemasan dan ketakutan di kalangan masyarakat yang berpengaruh terhadap pengaitan negative pada orang lain yang memiliki kemiripan tanda gejala dengan penyakit tersebut (WHO, 2020).

Stigma masyarakat terhadap orang terkonfirmasi positif virus corona mulai terasa di masyarakat. Sejalan dengan penelitian Abudi tahun 2020, dimana sebagian besar atau sebanyak $68 \%$ responden memiliki stigma terhadap orang yang terkonfirmasi positif covid 19. Stigma dapat memicu terjadinya pelanggaran HAM dan terjadinya diskriminasi pada orang/keluarga yang terkonfirmasi. Hal itu dapat memperparah pandemic covid -19 sehingga dapat menghambat pencegahan dan perawatan yang sudah ditetapkan (Abudi, Mokodompis, \& Magulili, 2020). Perilaku menstigma orang yang terkonfirmasi positif covid -19 juga mendorong keterpojokan orang yang terkonfirmasi dan mereka yang rentan 
terhadap infeksi virus ini (Herdiana, 2020). Hasil yang berbeda oleh Oktaviannoor dan Purnamasari dimana sebagian besar responden memiliki pengetahuan kategori tinggi dan sebagian besar tidak memberikan perilaku yang negatif terhadap orang yang terkonfirmasi positif covid -19 (Oktaviannoor, 2020) (Purnama, 2020).

Studi pendahuluan dilakukan di banjar Tegal, Desa Bebalang, Kabupaten Bangli, Provinsi Bali pada sepuluh kepala keluarga dengan teknik wawancara tentang tanggapan terhadap covid -19. Sebagian besar kepala keluarga atau sebanyak sembilan orang mengatakan cemas dan takut dengan orang-orang yang terkonfirmasi positif. Alasan yang paling mendasar adalah ketidaktahuan mereka dan kekhawatiran kepada pasien yang terkonfirmasi positif masih bisa menularkan. Berdasarkan hal tersebut peneliti tertarik untuk melakukan penelitian tentang hubungan antara pengetahuan dengan stigma pada orang terkonfirmasi positip corona virus disease -19 di Banjar Tegal, Desa Bebalang, Bangli, Provinsi Bali.

\section{METODE PENELITIAN}

Rancangan Penelitian
Deskriptif korelasi merupakan jenis penekitian yang digunakan dengan desain penelitian kuantitatif. Populasi adalah seluruh masyarakat di Banjar Tegal, Desa Bebalang, Kabupaten Bangli, Propinsi Bali yang berjumlah 1012 orang. Sampel dihitung dengan rumus Lemeshow kemudian dipilih sebanyak 89 dari masyarakat yang telah mengisi google form dan informed concent serta memenuhi kriteria inklusi dan ekslusi yaitu responden yang tidak menjalani karantina, usia diatas 18 tahun dan bisa baca tulis. Instrumen yang digunakan yaitu lembar kuesioner dengan 10 pertanyaan terkait pengetahuan dan 30 pertanyaan terkait stigma. Penelitian dilakukan pada tanggal 25 Desember 2020 sampai dengan delapan Januari 2021. Pengetahuan masyarakat tentang covid 19 diperoleh dari kemampuan individu dalam menjawab pertanyaan dalam kuesioner tentang pengertian covid -19 , tanda dan gejala, proses penularan, cara pencegahannya dan dampak yang ditimbulkan. Pengetahuan dikelompokkan menjadi tiga kategori yaitu pengetahuan kurang (skor $<56 \%$ ), cukup (skor 56-75\%) dan baik (skor 76$100 \%)$. 
Stigma terhadap orang (skor 61-90\%). Responden menjawab terkonfirmasi positif Covid 19 diperoleh kuesioner menggunakan media dari pengisian kuesioner yang berisi elektronik dengan aplikasi google form. segala pemikiran dan perilaku negatif Penyebaran google form dibantu oleh masyarakat terhadap orang yang bapak kelihan banjar melalui whatshap terkonfirmasi positif covid -19 yang group banjar. Uji statistik menggunakan dapat mempengaruhi aktivitas orang yang terkonfirmasi positif covid -19 program SPSS dengan analisis data menggunakan spearman rank.

dalam kehidupan sosial bermasyarakat.

Stigma dikelompokkan menjadi tiga

\section{HASIL DAN PEMBAHASAN} kategori yaitu stigma rendah (skor 0$30 \%$ ), sedang (skor 31-60\%) dan tinggi

\section{HASIL}

Karakteristik responden:

Tabel 1. Distribusi Karakteristik Responden Di Banjar Tegal, Desa Bebalang Bangli

Tahun 2021

\begin{tabular}{lll}
\hline Karakteristik & Frekuensi (n) & Persentase (\%) \\
\hline Umur & & \\
$26-35$ tahun & 52 & 58,40 \\
$36-45$ tahun & 3 & 29,20 \\
$46-55$ tahun & 8 & 3,40 \\
56-65 tahun & 7 & 9,00 \\
Pendidikan & 70 & \\
Tidak Sekolah & 33 & 7,90 \\
SD & 18 & 22,50 \\
SMP & 8 & 37,10 \\
SMA & 3 & 20,20 \\
Diploma & & 9,00 \\
Perguruan Tinggi & 13 & 3,40 \\
Pekerjaan & 16 & \\
Petani & 26 & 14,60 \\
PNS & 34 & 18,00 \\
Buruh & & 29,20 \\
Swasta & 52 & 38,20 \\
Jenis Kelamin & 37 & \\
Laki-laki & & 58,40 \\
Perempuan & & 41,60
\end{tabular}

Berdasarkan tabel 1 didapatkan hasil bahwa umur responden terbanyak pada tentang usia 26-35 tahun yaitu 52 orang (58,4\%). Pada karakteristik tingkat pendidikan terbanyak pada tinggkat SMP yaitu 33 orang $(37,1 \%)$. Pada karakteristik pekerjaan responden paling banyak memiliki pekerjaan swasta yaitu 
34 orang $(38,2 \%)$ serta paling banyak yaitu 52 orang $(58,4 \%)$.

responden berjenis kelamin laki-laki

Tabel 2. Tingkat Pengetahuan Masyarakat Tentang Covid-19 di Banjar Tegal Desa Bebalang Bangli Tahun 2021

\begin{tabular}{llcc}
\hline No & Pengetahuan & Frekuensi & Persentase (\%) \\
\hline 1 & Kurang & 11 & 12,4 \\
2 & Cukup & 65 & 73,0 \\
3 & Baik & 13 & 14,6 \\
\hline \multicolumn{2}{r}{ Total } & 89 & 100 \\
\hline
\end{tabular}

Berdasarkan tabel 2 didapatkan bahwa 19 sebagian besar dikategorikan cukup pengetahuan masyarakat tentang covid- $\quad$ yaitu sebanyak 65 orang (73\%).

Tabel 3. Stigma Terhadap Orang Terkonfirmasi Covid -19 di Banjar Tegal Desa Bebalang Bangli Tahun 2021

\begin{tabular}{ccccc}
\hline No & & Stigma & Frekuensi & Persentase (\%) \\
\hline $\mathbf{1}$ & Rendah & & 19 & 21,3 \\
$\mathbf{2}$ & Sedang & & 54 & 60,7 \\
$\mathbf{3}$ & Tinggi & & 16 & 18,0 \\
\hline & & Total & 89 & 100 \\
\hline
\end{tabular}

Berdasarkan tabel 3 didapatkan bahwa besar responden kategori sedang yaitu kejadian stigma terhadap orang sebanyak 54 orang $(60,7 \%)$. terkonfirmasi positif covid -19 sebagian

Tabel 4. Hasil Uji Statistik Tingkat Pengetahuan Dengan Stigma Pada Orang Terkonfirmasi Positip Corona Virus Disease -19 di Banjar Tegal Desa Bebalang Bangli Tahun 2021

\begin{tabular}{|c|c|c|c|c|c|c|c|c|c|c|c|}
\hline & & \multicolumn{6}{|c|}{ Stigma } & \multirow{2}{*}{\multicolumn{2}{|c|}{ Total }} & \multirow{3}{*}{$\begin{array}{c}\text { Nilai } \\
\mathbf{p}\end{array}$} & \multirow{3}{*}{$\begin{array}{c}\text { Nilai } \\
\mathbf{r}\end{array}$} \\
\hline & & \multicolumn{2}{|c|}{ Rendah } & \multicolumn{2}{|c|}{ Sedang } & \multicolumn{2}{|c|}{ Tinggi } & & & & \\
\hline & & $\mathrm{f}$ & $\%$ & $\mathrm{f}$ & $\%$ & $\mathrm{f}$ & $\%$ & $\mathrm{f}$ & $\%$ & & \\
\hline Pengetahuan & Kurang & 1 & 1,1 & 0 & 0 & 10 & 11,2 & 11 & 12,3 & 0,000 & $-0,548$ \\
\hline \multirow[t]{2}{*}{ Masyarakat } & Cukup & 9 & 10,1 & 52 & 58,4 & 4 & 4,5 & 65 & 73,0 & & \\
\hline & Baik & 9 & 10,1 & 2 & 2,2 & 2 & 2,2 & 13 & 14,7 & & \\
\hline \multicolumn{2}{|l|}{ Total } & 19 & 21,3 & 54 & 60,6 & 16 & 17,9 & 89 & 100 & & \\
\hline
\end{tabular}


Berdasarkan tabel 4. didapatkan bahwa dari 11 orang responden yang memiliki pengetahuan yang kurang, sebagian besar berada pada kategori stigma tinggi yaitu 10 orang $(11,2 \%)$ dan sebaliknya, 13 responden yang memiliki pengetahuan baik, sebagian besar berada pada kategori stigma rendah yaitu 9 orang $(10,1 \%)$. Berdasarkan hasil analisis didapatkan nilai $p$ value sebesar 0,000 dan nilai $r$ sebesar $-0,548$ yang berarti H0 ditolak dan Ha diterima, ada hubungan tingkat pengetahuan dengan stigma pada orang terkonfirmasi positip corona virus disease -19 di Banjar Tegal, Desa Bebalang, Bangli Propinsi Bali dengan korelasi hubungan yang kuat dilihat dari nilai $r=-0,548$ dan arah hubungan yang negatif dimana semakin baik pengetahuan masyarakat terhadap covid -19, maka semakin rendah stigma terhadap orang terkonfirmasi covid -19 .

\section{PEMBAHASAN}

\section{Pengetahuan Tentang Covid -19}

Pada penelitian ini didominasi dengan pengetahuan dengan kategori cukup. Menurut Notoatmodjo dan Wawan, pengetahuan diperoleh dari hasil tau seseorang berdasarkan kolaborasi dari penginderaan yang dimiliki oleh manusia serta beberapa faktor lain yang mempengaruhi pengetahuan diantaranya usia, jenis pekerjaan, tingkat Pendidikan, sosial budaya dan faktor lingkungan (Notoatmodjo, 2012) (Wawan, 2011).

Hasil penelitian ini didukung oleh penelitian kualitatif dengan jumlah sampel 144 orang yang dilakukan oleh purnamawati di wonosobo tentang tingkat pengetahuan dan perilaku masyarakat terkait covid-19 mendapat hasil sebagian besar dengan kategori cukup (90\%). Factor eksternal sangat berpengaruh terhadap penerimaan dan pemahaman masyarakat terkait informasi yang diperoleh walaupun telah mendapat informasi yang sama (Purnama, 2020).

Berbeda dengan penelitian yang dilakukan oleh Moudy, sebanyak 76,9\% responden berada pada kategori baik tentang pengetahuan terkait pencegahan penyebaran covid-19. Moudy menegaskan bahwa sikap akan dipengaruhi oleh pengetahuan yang dimiliki oleh individu dimana pengetahuan yang baik akan meningkatkan rasa percaya diri masyarakat untuk menghadapi pandemic covid-19 (Moudy \& Syakurah, 2020). 
Aspek positif dan negative yang terkandung didalam pengetahuan seseorang akan berpengaruh terhadap sikap seseorang, dimana semakin banyak aspek negative pengetahuan yang dimiliki terhadap suatu objek maka sikap terhadap objek tersebut makin negative, begitu juga sebaliknya. Arah perbuatan dan pemilihan perbuatan yang akan dilakukan guna mencapai tujuan berasal dari pengetahuan. Pengetahuan yang baik diharapkan menghilangkan perbuatan-perbuatan atau sikap yang tidak bermanfaat sehingga dapat mengrangi stigma yang terjadi di masyarakat. Pendidikan kesehatan merupakan salah satu hal yang bisa diterapkan dimasyarakat untuk menambah pengetahuan terkait covid 19 sehingga dapat dijadikan acuan untuk mengambil sikap dalam kehidupan bermasyarakat. Pada penelitian ini, sebagian besar dengan pengetahuan sedang, hal ini kemungkinan disebabkan oleh $58,40 \%$ usia responden berada pada rentang usia 26-35 tahun. Usia 26-35 tahun merupakan usia melek teknologi untuk mendapatkan segala informasi terkait covid 19 sehingga segala informasi dapat diakses secara luas.
Stigma Terhadap Orang Terkonfirmasi Positif Corona Virus Disease -19 (Covid 19)

Hasil penelitian ini didominasi oleh responden dengan stigma kategori sedang. Dai menyebutkan bahwa stigma di masyarakat dalam bentuk kekerasan fisik, penolakan social, penolakan layanan dan gossip muncul apabila masyarakat melihat adanya sesuatu yang dianggap menyimpang dari sesuatu yang dianggap normal (Dai, 2020).

Sejalan dengan penelitian yang dilakukan oleh Rahman di Yogyakarta bahwa dominan responden memiliki sikap stigma cukup tinggi yaitu sebesar $63,4 \%$. Ketika seseorang dinyatakan terkonfirmasi covid -19, stigma merupakan suatu ancaman besar. Seseorang terlanjur diberi label pembawa penyakit yang berbahaya bagi masyarakat sehingga seorang yang terkonfirmasi berpotensi mengalami pengucilan dalam waktu yang lama. stigma sosial dapat memunculkan fenomena social yang berpotensi memperparah situasi bagi orang atau keluarga yang mengalami gejala penyakit tertentu (Dai, 2020).

Beberapa point yang dapat dilakukan guna mengurangi stigma yang terjadi di masyarakat yaitu 
membicarakan risiko covid- 19 secara akurat yang berdasar data ilmiah dan saran kesehatan resmi terbaru, berbicara secara positip dan menekankan efektivitas tindakan pencegahan dan pengobatan, serta tekankan efektivitas langkah-langkah perlindungan untuk mencegah tertular virus, serta pemeriksaan, pengujian dan pengobatan dini (WHO, 2020).

Stigma dalam kategori sedang pada penelitian ini, kemungkinan disebabkan oleh salah satunya usia dan tingkat pendidikan, dimana untuk rentang usia 26-35 tahun merupakan usia yang melek teknologi. Apabila dikaitkan dengan tingkat pendidikan yang sebagian besar pada tingkat SMP, maka kemungkinan informasi yang didapat dari media sosial belum dipilah terkait dengan kebenaran informasi yang didapatkan. Informasi yang salah atau belum tentu kebenarannya dapat memengaruhi perilaku atau tindakan yang dilakukan di masyarakat. Adapun kontribusi yang bisa dilakukan sebagai individu untuk mengurangi stigma yaitu dengan mengikuti arahan yang ditetapkan oleh pemerintah serta memberikan simpati dan empati bagi individua tau keluarga yang terdampak pandemi covid-19.
Penelitian ini mendapat hasil ada hubungan tingkat pengetahuan dengan stigma pada orang terkonfirmasi positip corona virus disease -19 di Banjar Tegal, Desa Bebalang, Bangli Provinsi Bali. Dapat dilihat bahwa semakin baik pengetahuan seseorang, stigma terhadap orang positif covid-19 semakin rendah. Pengetahuan seseorang sangat berpengaruh dalam perilaku seseorang (Notoatmodjo, 2012). Pengetahuan yang tidak memadai terkait informasi cara penularan, tanda gejala, pencegahan dan pengobatan terkait covid-19 akan meningkatkan terjadinya stigma di masyarakat. Informasi yang akurat, bahasa sederhana, melibatkan selebritis, tokoh agama, pimpinan pemerintah dengan fasilitas media social yang menjangkau seluruh lapisan masyarakat dapat digunakan sebagai salah satu langkah untuk mengurangi atau menghapus stigma yang terjadi di masyarakat (Adebayo, 2016).

Oktaviannoor di Banjarmasin mendapatkan hasil penenelitian yang sejalan, dimana terdapat hubungan signifikan antara pengetahuan dengan stigma pasien dan tenaga Kesehatan yang terconfirmasi positip covid-19. Tinggi rendahnya tingkat pengetahuan individu sangat berpengaruh terhadap 
stigma yang terjadi di msyarakat (Oktaviannoor et al,2020).

Rahman di Yogyakarta mendapatkan hasil yang berbeda, tidak ada hubungan antara pengetahuan dengan stigma masyarakat terhadap orang yang terkait dengan covid-19. Pemahaman yang keliru terkait informasi dan aturan yang ada merupakan salah satu factor munculnya stigma. Menjaga jarak yang merupakan salah satu upaya pencegahan penularan covid-19 berdasarkan rekomendasi WHO disalahartikan. Pada hasil penelitian yang dilakukan oleh Rahman sikap stigma dalam kategori cukup cenderung dilakukan oleh seseorang dengan pengetahuan tinggi (Rahman et al, 2021).

Diskriminasi terhadap individu yang terkonfirmasi positip covid-19 akan tetap terjadi apabila stigma masih ada di masyarakat (Herdiana, 2020). Menurut faktor-faktor penyebab terbentuknya stigma salah satunya adalah pengetahuan. Stigma terbentuk karena ketidaktahuan dan kurangnya pengetahuan seseorang (Moudy \& Syakurah, 2020).

Stigma yang terjadi di masyarakat dapat menyebabkan pencegahan penularan semakin sulit, orang lebih memilih tidak diperiksa untuk menghindari stigma. Menurut Muslih, komunikasi yang dituangkan dalam bentuk kata-kata ataupun ekspresi saling menguatkan, dapat meningkatkan rasa simpati dan empati serta motivasi bagi diri sendiri maupun orang lain (Muslih, 2020). Salah satu wadah yang sangat cocok diakses pada masa pandemi untuk saling memberi dukungan dan motivasi terkait cara menghadapi pandemi kepada keluarga dan kepada orang lain adalah media sosial (Sampurno et al, 2020). Pemberian informasi dalam bentuk penyuluhan di masyarakat sangat penting dilakukan, terutama informasi terkait penularan, tanda gejala, pencegahan dan pemeriksaan apabila dirasa memiliki gejala yang mirip dengan covid-19.

Jumlah sampel dan metode yang digunakan dalam penelitian ini berbeda dengan beberapa penelitian yang lain, sehingga memungkinkan untuk mendapat hasil yang berbeda pula. Pengambilan data tidak dapat dilakukan secara langsung terkait adanya pandemi sehingga penelitian ini memiliki keterbatasan dimana penyebaran kuesioner menggunakan google form yang tidak dapat menjangkau 
masyarakat yang tidak memiliki alat komunikasi yang mendukung.

\section{KESIMPULAN}

Ada hubungan tingkat pengetahuan dengan stigma pada orang terkonfirmasi positip corona virus disease -19 di Banjar Tegal, Desa Bebalang, Bangli Provinsi Bali dengan korelasi hubungan yang kuat dengan arah hubungan yang negatif.

\section{UCAPAN TERIMAKASIH}

Kepada Ketua STIkes Wira Medika Bali dan Tim LPPM STIKes Wira Medika Bali yang telah membantu terwujudnya penelitian ini.

\section{DAFTAR PUSTAKA}

Abudi, R., Mokodompis, Y., \& Magulili, A. N. (2020). Stigma Terhadap Orang Positif Covid-19 (Stigma Against Positive People Covid-19). Jambura Journal of Health Sciences and Research, 2(2), 77-84. Retrieved from https://papers.ssrn.com/sol3/papers. cfm?abstract_id $=3582624$

Adebayo, F. (2016). Renewing media and public attention to the AIDS pandemic in sub-Saharan Africa in the post-2015 development agenda: A reflective perspective. African Journal of Political Science and International Relations, 10(1), 1-7. https://doi.org/10.5897/ajpsir2015. 0825

Ai, T., Yang, Z., Hou, H., Zhan, C., Chen, C., Lv, W., ... Xia, L. (2020). Correlation of Chest CT and RT-PCR Testing for Coronavirus Disease 2019 (COVID-19) in China: A Report of 1014 Cases. Radiology, 296(2), E32-E40.

https://doi.org/10.1148/radiol.2020 200642

Dai, N. F. (2020). Stigma Masyarakat Terhadap Pandemi Covid-19. Prodi Ilmu Keperawatan Universitas Indonesia Timur, 66-73.

Dennison Himmelfarb, C. R., \& Baptiste, D. (2020). Coronavirus Disease (COVID-19). Journal of Cardiovascular Nursing, Vol. 35, pp. 318-321. https://doi.org/10.1097/jen.000000 0000000710

Muslih, B. (2020). Urgensi Komunikasi dalam Menumbuhkan Motivasi di Era Pandemi Covid 19. Jurnal Penelitian Manajemen Terapan 
Panataran. Vol.5 No. 1 57-65.

Hasil Survey Sosial Demografi. (2020).

Dampak Covid 19.

Herdiana, I. (2020). Stigma Saat Pandemi COVID-19 dan Tindakan Melawannya. Psychology, 10.

Homepage - Info Corona Pemerintah Provinsi Bali. (2021).

Kasus Covid Indonesia 29 April 2021 Penelusuran Google. (2021).

Moudy, J., \& Syakurah, R. A. (2020). Pengetahuan terkait usaha pencegahan Coronavirus Disease (covid-19) di Indonesia. Higeia Journal of Public Health Research and Development, 4(3), 333-346.

Notoatmodjo, S. (2012). Promosi Kesehatan \& Ilmu Perilaku. Jakarta: Rineka Cipta.

Oktaviannoor, H., Herawati, A., Hidayah, N., Martina, M., \& Hanafi, A. S. (2020). Pengetahuan dan stigma masyarakat terhadap pasien Covid-19 dan tenaga kesehatan di Kota Banjarmasin. Dinamika Kesehatan: Jurnal Kebidanan Dan Keperawatan, 11(1), 98-109. https://doi.org/10.33859/dksm.v11i 1.557
Purnama, S. dan A. E. R. (2020). Tingkat Pengetahuan dan Perilaku Masyarakat Kabupaten Wonosobo Tentang Covid-19. 1, 1, 10.

Rahman, N. E., Tyas, A. W., \& Nadhilah, A. (2021). Hubungan Pengetahuan Tentang Covid-19 Terhadap Sikap Stigma Masyarakat Pada Orang Yang Bersinggungan Dengan Covid-19. Share: Social Work Journal, 10(2), 209. https://doi.org/10.24198/share.v10i 2.29614

Sampurno, M. B. T., Kusumandyoko, T. C., \& Islam, M. A. (2020). Budaya Media Sosial, Edukasi Masyarakat, dan Pandemi covid-19. SALAM: Jurnal Sosial Dan Budaya Syar-I, $7(5)$.

https://doi.org/10.15408/sjsbs.v7i5. 15210

Susilo, A. (2020). Coronavirus Disease 2019: Tinjauan Literatur Terkini Coronavirus Disease 2019 : Review of Current Literatures. 1.

Wawan, D. M. (2011). Teori Dan Pengukuran Pengetahuan, Sikap Dan Perilaku Manusia Dilengkapi Contoh Kuesioner (pp. 15-16). pp. 15-16.

WHO. (2020). Stigma Sosial terkait dengan covid-19. 